\title{
Birnam Woods, Moving Closer, Shadows Our Work
}

\author{
Steven N. Handel
}

The impossibility of a forest that could move served to quiet fears of the future for a troubled king:

Apparition:

Macbeth shall never vanquish'd be until

Great Birnam wood to high Dunsinane hill

Shall come against him.

Macbeth responds:

That will never be

Who can impress the forest, bid the tree

Unfix his earth-bound root?

(Macbeth, Act 4, scene 1)

hen, in one of the play's most vivid scenes, it happened. Soldiers masked by tree boughs marched through Scotland towards the king, and his terrify-

ing fate, once impossible to imagine, unfolds.

We now move from ancient literature to the feckless present, from the playwright's imagination to our reality of escalating climate change and its biotic consequences. With the globe warming, the distributions of land and sea species may move, as each entity's spatial niche changes location (or disappears). There is a dynamic relationship between the removal of the appropriate climatic envelope for a species and its ability to move to a place where the migrating favorable climate can be found. Movement of diaspores depends on wind, water currents, or mutualists, and for plants, speed of movement may not match the rate of loss of favorable locations. The speed of movement is also slowed for most species by the physical barriers that people have added to the landscape. Roads, tall buildings, agricultural and sports fields all can slow movement of diaspores and the consequent establishment of new populations. Climate continues to change potential vegetation zones, but seed carriers may not keep pace. Loss of range results.

Many surveys have shown that trees, insects, and other taxa have already moved beyond their historic zones because of climate change. Public agencies have cataloged

Ecological Restoration Vol. 37, No. 1, 2019

ISSN 1522-4740 E-ISSN 1543-4079

(O2019 by the Board of Regents of the University of Wisconsin System. 


\section{Recommended Readings}

Aitken, S.N., S. Yeaman, J.A. Holliday, T. Wang and S. Curtis-McLane. 2008. Adaptation, migration or extirpation: climate change outcomes, for tree populations. Evolutionary Applications 1:95-111.

Chen, I.C., J.K. Hill, R. Ohlemüller, D.B. Roy and C.D. Thomas. 2011. Rapid range shifts of species associated with high levels of climate warming. Science 333:1024-1026.

Grimm, N.B., F.S. Chapin, B. Bierwagen, P. Gonzalez, P.M. Groffman, Y. Luo, et al. 2013. The impacts of climate change on ecosystem structure and function. Frontiers in Ecology and the Environment 11:474-482.

Hällfors, M.H., S. Aikio and L.E. Schulman. 2017. Quantifying the need and potential of assisted migration. Biological Conservation 205:34-41.

Iverson, L.R., M.W. Schwartz and A.M. Prasad. 2004. How fast and far might tree species migrate in the eastern United States due to climate change? Global Ecology and Biogeography 13:209-219.
Loss, S.R., L.A. Terwilliger and A.C. Peterson. 2011. Assisted colonization: integrating conservation strategies in the face of climate change. Biological Conservation 144:92-100.

Ricciardi, A. and D. Simberloff. 2009. Assisted colonization is not a viable conservation strategy. Trends in Ecology \& Evolution 24:248-253.

Thomas, C.D., 2011. Translocation of species, climate change, and the end of trying to recreate past ecological communities. Trends in Ecology \& Evolution 26:216-221.

U.S. Global Change Research Program. 2018. Fourth National Climate Assessment. Volume II: Impacts, Risks, and Adaptation in the United States. nca2018.globalchange.gov.

Zhu, K., C.W. Woodall and J.S. Clark. 2012. Failure to migrate: lack of tree range expansion in response to climate change. Global Change Biology 18:1042-1052.

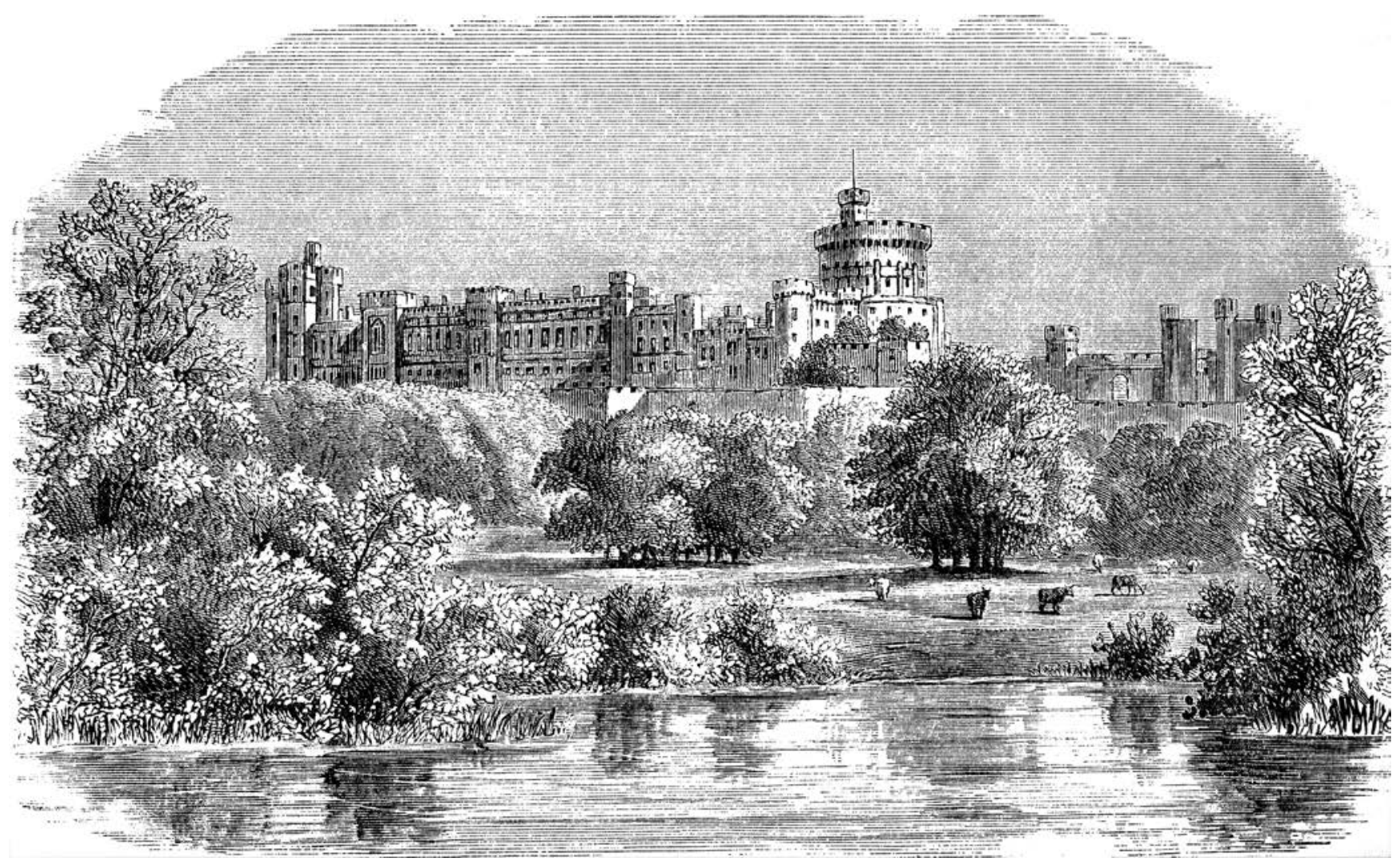

Windsor castle and the surrounding woodland. Donald, R. 1871. Wonders of Architecture. New York, NY: Charles Scribner \& Co. The Florida Center for Instructional Technology, fcit.usf.edu. 